\title{
PENGARUH KECERDASAN EMOSIONAL DAN KOMPETENSI TERHADAP KINERJA PEGAWAI
}

\author{
Irma Mulyasari ${ }^{1}$ \\ ${ }^{1}$ Program Studi Manajemen Pascasarjana Universitas Galuh Ciamis \\ email: irmamulya90@gmail.com
}

\author{
Article History : \\ Received5 February 2018 \\ Recieved in revished form \\ 19February 2018 \\ Acepted 5May 2018 \\ Available offline20 May 2018 \\ Available online 20 May 2018
}

Language Transcript :

Indonesia (id)

Key Words :

Kecerdasan Emosional

Kompetensi

Kinerja Pegawai

\begin{abstract}
Tujuan dari penelitian ini adalah untuk mencari tahu bagaimana pengaruh kecerdasan emosional dan kompetensi secara simultan terhadap kinerja pegawai pada penyuluh $K B$ di BKBPPKabupaten Garut. Metode yang digunakan dalam penelitian ini menggunakan metode kuantitatif. Untuk menganalisanya menggunakan analisa data uji statistik korelasi dan regresi ganda dengan menggunakan program SPSS. Hasil analisis membuktikan bahwa : 1) Kecerdasan emosional berpengaruh positif dan signifikan terhadap kinerja pegawai. Artinya semakin baik kecerdasan emosional maka semakin meningkat pula kinerja pada Penyuluh Badan Keluarga Berencana dan Pemberdayaan Perempuan (BKBPP) Kabupaten Garut. Lebih lanjut berkenaan dengan kecerdasan emosional ditemukan indikator yang perlu lebih dioptimalkan berkenaan dengan keterampilan dalam berkomunikasi; 2) Kompetensi berpengaruh positif dan signifikan terhadap kinerja pegawai. Artinya semakin baik kompetensi maka semakin meningkat pula kinerja pada Penyuluh Badan Keluarga Berencana dan Pemberdayaan Perempuan (BKBPP) Kabupaten Garut. Lebih lanjut berkenaan dengan kompetensi ditemukan indikator yang perlu lebih dioptimalkan berkenaan dengan daya tanggap terhadap masalah; 3) Kecerdasan emosional dan kompetensi berpengaruh positif dan signifikan terhadap kinerja pegawai. Artinya semakin baik kecerdasan emosional dan kompetensi maka semakin meningkat pula kinerja pada Penyuluh Badan Keluarga Berencana dan Pemberdayaan Perempuan (BKBPP) Kabupaten Garut.
\end{abstract}

\section{PENDAHULUAN}

Badan KBPP Kabupaten Garut berupaya untuk meningkatkan peran dan fungsinya untuk meningkatkan daya saing mutu pelayanan melalui peningkatan kecerdasan emosional dan kompetensi pegawai yang diwujudkan sebagai kemampuan hardskill dan soft skill para pegawai, hal ini merupakan kebijakan yang sangat strategis. Karena itu untuk ikut menyukseskan tujuan BKKBN Pusat, Badan KBPP Kabupaten Garut, selainmenyelanggarakan berbagai pelatihan khusus untuk meningkatkan kompetensi pegawai dalam penguasaan program KB secara menyeluruh, juga diberikan pembinaan dan pembekalan untuk meningkatkan kecerdasan emosional bagi pegawai dalam hal ini adalah Penyuluh KB (PKB) di lingkungan Badan KBPP Kabupaten Garut.

PKB merupakan ujung tombak dari peningkatan program KB di lini lapangan, dimana tugas pokoknya adalah memberikan pelayanan berupa Penyuluhan mengenai program KB kepada masyarakat, mengajak, memotivasi dan mengayomi setiap keluarga 
agar mengikuti Program KB sesuai dengan Visi dan Misi BKKBN. Visi BKKBN adalah Penduduk Tumbuh Seimbang 2015, dan Misi BKKBN adalah Mewujudkan Pembangunan Yang Berwawasan Kependudukan dan Mewujudkan Keluarga Kecil Bahagia dan Sejahtera. Dalam melaksanakan tupoksinya, seorang PKB dituntut untuk mempunyai kompetensi yang tinggi sesuai dgn tupoksinya agar masyarakat mengetahui secara menyeluruh tentang program $\mathrm{KB}$ dan menjadikan Program KB sebagai suatu kebutuhan untuk kelangsungan hidupnya, dan bukan lagi sebagai paksaan seperti paradigma yang berkembang di masyarakat selama ini.

Untuk merubah mindset masyarakat yang selama ini menganggap program $\mathrm{KB}$ adalah suatu program pemerintah yang tidak penting (karena tidak dapat dirasakan langsung manfaatnya oleh masyarakat berbeda dengan program - program pemerintah lainnya), itu bukan lah pekerjaan yang mudah, apalagi dengan kondisi masyarakat seperti yang disebutkan diatas, untuk itu akan dibutuhkan seorang PKB yang mempunyai kompetensi yang baik dibidangnya juga dibekali dengan kecerdasan emosional yang tinggi.

Perbaikan mutu lembaga dalam pelayanan publik dengan mengembangkanhardskill dan soft skillserta upaya peningkatan kecerdasan emosional di lembagaharuslah berlandaskan tiga proses yaitu (1) perencanaan, (2) pelaksanaan, dan (3) evaluasi". Dari ketiga proses tersebut peran penting para pelaksana kebijakan sangat berpengaruh, sehingga tanpa pengertian dan kesadaran dari pelaksana kebijakan mengenai pentingnya pengembangan kecerdasan emosional bagi masyarakat, perbaikan mutu pelayanan tidak akan dapat tercapai dengan baik.

Dampak dari globalisasi pada beberapa lembaga terlihat dari banyaknya pegawai yang tidak professional.Salah satu penyebab para pegawai yang tidak professional adalah karena kurangnya kecerdasan emosional para pegawai tersebut. Berdasarkan kajian Kelompok Kerja Lapangan (KKL) Badan KBPP Kab.Garut, berkenaan dengan mutu kerja pegawai diperoleh informasi seperti pada tabel 1.1 di bawah ini :

Tabel 1.1 Kajian Terhadap Peningkatan Kecerdasan

\begin{tabular}{|c|l|c|}
\hline No & \multicolumn{1}{|c|}{ Aspek yang dikaji } & $\begin{array}{c}\text { Besarnya } \\
\text { Peningkatan }\end{array}$ \\
\hline 1 & Kecerdasan Intelegensia & $65,0 \%$ \\
\hline 3 & Kecerdasan Emosional & $60,5 \%$ \\
\hline 4 & Kecerdasan Spiritual & $72,5 \%$ \\
\hline \multicolumn{2}{|l|}{ Sumber : Laporan kerja KKLBKBPP Kab. Garut 2015 } \\
\hline
\end{tabular}

Berdasarkan data tersebut pada tabel, ternyata bahwa peningkatan aspek kecerdasan spiritual memiliki nilai yang lebih tinggi dibanding dengan kecerdasan yang lainnya termasuk kecerdasan emosional.Oleh karena itu diperlukan kajian ilmiah secara khusus, berkenaan dengan aspek kecerdasan emosional seseorang terhadap nilai kinerja karena peningkatan kecerdasan emosional sangat rendah nilainya dibanding dengan kecerdasan intelegensia dan kecerdasan spiritual.

Efektivitas organisasi dan kinerja pegawai yang hasilnya diwujudkan dengan besarnya produktivitas kerja yang pada dasarnya mencakup sikap mental dan emosional yang memandang hari depan penuh optimis berdasarkan keyakinan bahwa hari ini harus lebih baik dari hari kemarin. Produktivitas memerlukan keterampilan kerja yang sesuai dengan substansi kerja sehingga bisa menghasilkan inovasi dan strategi tepat untuk memperbaiki dan meningkatkan kinerja, atau minimal mempertahankan kinerja yang sudah dianggap baik.

Efektivitas organisasi dan kinerja pegawai perlu didukung oleh kemauan yang tinggi (motivasi), kemampuan kerja (kompetensi) yang sesuai dengan substansi kerja yang disyaratkan, lingkungan yang nyaman dan 
kondusif, jaminan penghasilan yang dapat memenuhi kebutuhan hidup minimum, jaminan sosial yang memadai, kondisi kerja yang manusiawi, serta hubungan kerja yang harmonis.

Dengan demikian, produktivitas lembaga akan berkaitan dengan tingkat kualitas kerja dan kepuasan maksimum yang akan dirasakan oleh setiap pegawai. Saat ini Badan BKBPP Kabupaten Garutjuga menghadapi berbagai kendala dan masalah seperti fasilitas dan sarana yang tidak memadai, kesejahteraan pegawai dan tenaga lapangan yang rendah, program yang overload, methode pelayanan yang hanya memperhatikan dimensi kognitif saja dan lembaga seolah kehilangan relevansinya dengan pembentukan karakter.

Sebagai konsekuensinya lembaga lebih merupakan tempat bagi sosialisasi daripadapembangunan karakter (character building).Salah satu dimensi kualitas manusia yaitu karakter, belum mampu dibentuk melalui sistem pendidikan Indonesia.Paradigma rasionalistik yang dianut Orde baru sedemikian kuat sehingga nyaris setiap bidang kehidupan kita tercemari olehnya. Padahal konsep kecerdasan otak (inteligensi) sebagai sumber keberhasilan kini kadaluarsa.Seperti ditunjukkan penelitian mutakhir terdapat kecerdasan lain yang jauh lebih berperan bagi keberhasilan seseorang, yakni kecerdasan emosional dan kecerdasan spiritual (soft skill).

Tugas pokok dan fungsi Badan KB dan Pemberdayaan Perempuan Kabupaten Garut dalam Program keluarga berencana adalah : (1) Penyediaan alat pelayanan KB dan alat Kontrasepsi bagi keluarga miskin; (2) Pelayanan KIE; (3) Peningkatkan perlindungan hak Reproduksi Remaja(KRR); (4) Promosi pelayanan KB; (5) Pembinaan keluarga Berencana; (6) Pengadaan Sarana mobilitas tim KB keliling.
Berdasarkan paparan tersebut di atas, dapat digambarkan bahwa Badan KBPP Kabupaten Garut menghadapi beban permasalahan kerja yang harus dilakukan secara strategis demi terwujudkan Visi dan Misi BKKBN yaitu Penduduk yang tumbuh seimbang dengan kondisi masyarakat yang bermartabat, nyaman dan sejahtera. Namun untuk mewujudkan hal tersebut, diperlukan kinerja pegawai yang berkualitas tinggi. Adapun gambaran sementara berkenaan dengan kualitas kerja dapat dilihat dari hasil evaluasi Sasaran Kinerja Pegawai (SKP) seperti dideskripsikan pada tabel di bawah ini :

Tabel 1.2 Evaluasi Sasaran Kinerja Pegawai

\begin{tabular}{|c|l|l|l|}
\hline No & Jenis Evaluasi SKP & $\begin{array}{l}\text { Rerata } \\
\text { Hasil } \\
\text { Penilaian }\end{array}$ & Kategori \\
\hline 1 & $\begin{array}{l}\text { Rerata Hasil Penilaian } \\
\text { Sasaran Kinerja Pegawai }\end{array}$ & 74,22 & $\begin{array}{l}\text { Cukup } \\
\text { Baik }\end{array}$ \\
\hline 2 & $\begin{array}{l}\text { Rerata Hasil Penilaian } \\
\text { Etika Pegawai }\end{array}$ & 70,66 & $\begin{array}{l}\text { Cukup } \\
\text { Baik }\end{array}$ \\
\hline
\end{tabular}

Berdasarkan data pada tabel di atas, baik sasaran kerja pegawai dan penilaian etika kerja pegawai, dan sekalipun kategori hasil penilaian dikategorikan baik, namun masih menyisakan angka hilang artinya kinerja pegawai masih belum optimal, atau mungkin masih diperlukan penilaian aspek lain dan solusi strategis yang harus direncanakan dalam upaya peningkatan optimalisasi target penilaian kinerja pegawai hingga angka minimal 95,00. Selain itu Hasil kerja Penyuluh KB berupa Target Ketercapaian Akseptor KB aktif adalah $78 \%$ dan didominasi oleh nonMKJP, suntik 53,8\% dan pil $22 \%$. Penggunaan MKJP masih rendah yang hanya mencapai $18,5 \%$ dari target $27,5 \%$ dan cenderung menurun. Pencapaian Target Akseptor KB Baru adalah 2,8\% masih sangat rendah.

Dari deskripsi di atas, dimana kinerja pegawai khususnya pada Badan KBPP dinilai belum optimal, dimungkinkan 
disebabkan karena dua aspek penting yang belum diperhatikan, diantaranya kekuatan sumber daya manusia atau pegawai yakni lemahnya kecerdasan emosinal pegawai yang mampu membangun mentalitas pegawai untuk memiliki idealisme, komitmen dan keteguhan diri agar tetap berada pada pertimbangan keputusan tindak dalam menjalankan tugas sebaik mungkin. Disamping kelemahan dalam potensi kecerdasan emosional pegawai, terdapat variabel kompetensi pegawai, yakni kemampuan dasar yang dimiliki pegawai dalam melaksanakan tugas pokok, fungsi dan kewenangannya.

\section{METODOLOGI}

Penelitian ini menggunakan metode penelitian kuantitatif (Quantitative Research) dengandesain penelitian yang digunakan menggunakan penelitian korelasional untuk mengetahui tingkat hubungan antara dua variabel tersebut. Alat pengumpulan data yang digunakan menggunakan teknik observasi, dokumentasi dan penyebaran angket. Selanjutnya untuk tehnik pengolahan data dan analisis data dilakukan dengan cara 1). Mengukur setiap variabel yang diteliti. 2). Mengukur hubungan (korelasi) antar variabel, dan 3). Mengukur besarnya pengaruh antar variabel. Untuk mempermudah perhitungan penelitian peneliti menggunakan program komputer SPSS versi 18.00 for windows.

Subjek penelitian adalah pegawai Penyuluh Badan Keluarga Berencana dan Pemberdayaan Perempuan (BKBPP) Kabupaten Garut. Sedangkan objek penelitiannya adalah kecerdasan emosional $\left(\mathrm{X}_{1}\right)$, dan kompetensi $\left(\mathrm{X}_{2}\right)$ serta kinerja pegawai (Y). Populasi dalam penelitian ini adalah seluruh pegawai Penyuluh Badan KBPP Kabupaten Garut yang berjumlah 237 pegawai.

\section{HASIL DAN PEMBAHASAN}

\section{1 Pengaruh Kecerdasan Emosional Terhadap Kinerja Pegawai}

Dari hasil penelitian membuktikan bahwa terdapat pengaruh antara kecerdasan emoisonal terhadap kinerja pegawai. Artinya semakin tinggi kecerdasan emoisonal maka akan semakin baik pula kinerja egawai. Sebaliknya, semakin rendah kecerdasan emoisonal yang dilakukan maka akan semakin rendah pula kinerja Penyuluh Badan Keluarga Berencana dan Pemberdayaan Perempuan (BKBPP) Kabupaten Garut.

Hal tersebut senada yang diungkapkan Daniel Goleman (Hariwijaya, 2005: 7) mengungkapkan bahwa kecerdasan emosi adalah :(1) Kemampuan seseorang untuk mengenali emosi pribadinya sehingga tahu kelebihan dan kekurangnnya; Kemampuan sesorang untuk mengelola emosi tersebut; (3) Kemampuan seseorang untuk memotivasi dan memberikan dorongan untuk maju kepada diri sendiri; (4) Kemampuan seseorang untuk mengenal emosi dan kepribadian orang lain; (5) Kemampuan seseorang untuk membina hubungan dengan pihak lain secara baik. Jika kita memang mampu memahami dan melaksanakan kelima wilayah utama kecerdasan emosi tersebut, maka semua perjalanan bisnis atau karier apapun yang kita lakukan akan lebih berpeluang berjalan mulus.

Beberapa aspek yang menjadi karakteristik umum kecerdasan diantaranya adalah : (a) Kemampuan untuk belajar dan mengambil manfaat dari pengalaman; (b). Kemampuan untuk belajar atau menalar secara abstrak; (c) Kemampuan untuk beradaptasi terhadap hal-hal yang timbul dari perubahan dan ketidakpastian lingkungan; (d) Kemampuan untuk memotivasi diri guna menyelesaikan secara tepat tugastugas yang perlu diselesaikan. 
Menurut pandangan para ahli dapat disimpulkan bahwa kecerdasan atau Inteligensi adalah kemampuan untuk menguasai kemampuan tertentu. Inteligensi atau kecerdasan adalah suatu kekuatan atau kemampuan untuk melakukan sesuatu. kinerja diartikan sebagai "Performance is ability to perform, capacity achieve and desired result (Webster third). (New International dictionary ; 1966)".Kinerja didalam kamus bahasa Indonesia (1994 ; 503) dikatakan bahwa kinerja merupakan : (1) sesuatu yang dicapai (2) prestasi yang diperlihatkan (3) Kemampuan kerja. Sehingga dapat disimpulkan bahwa kinerja merupakan hasil kerja yang dihasilkan oleh pegawai atau karyawan dalam melakukan tugas dan tanggung jawabnya.

Selanjutnya Mangkunegara (2005 : 9), mengemukakan bahwa: "Kinerja karyawan (prestasi kerja) adalah hasil kerja secara kulaitas dan kuantitas yang dicapai oleh seseorang karyawan dalam melaksanakan tugasnya sesuai dengan tanggung jawab yang diberikan kepadanya". Dengan demikian maka hubungan antara kecerdasan emosional dengan kinerja pegawai secara rasional dan empirik dapat diterima memiliki hubungan konsep dan determinasi yang saling ketergantungan.

\section{2 Pengaruh Kompetensi Terhadap Kinerja Pegawai}

Dari hasil penelitian membuktikan bahwa terdapat pengaruh antara kompetensi terhadap kinerja pegawai. Artinya semakin maksimal kompetensi maka akan semakin baik pula kinerja pegawai. Sebaliknya, semakin rendah kompetensi maka akan semakin rendah pula kinerja Penyuluh Badan Keluarga Berencana dan Pemberdayaan Perempuan (BKBPP) Kabupaten Garut.

Hal ini sependapat menurut Prihadi (2004) menyatakan mengenai pentingnya kompetensi sebagai berikut : A Cluster of related knowledge, skills, and attitudes that http://jurnal.unigal.ac.id/index.php/managementreview

affects a major part of one's job (role or responsibility), that correlates withperformance on the job, that can be measured against well-accepted standards, and that can be improved via training and development, kompetensi adalah seperangkat pengetahuan, keterampilan, dan sikap yang saling terkait mempengaruhi sebagian besar jabatan (peranan atau tanggung jawab), berkorelasi dengan kinerja pegawai pada jabatan tersebut, dan dapat diukur dengan standar-standar yang dapat diterima, serta dapat ditingkatkan melalui upaya-upaya pelatihan dan pengembangan"

Kemudian hal ini sejalan dengan pendapat Suparno (2005:24) yang menyatakan bahwa :Competency refers to an individual's knowledge, skill, ability or personality characteristics that directly influence job performance.Artinya, kompetensi mengandung aspek-aspek pengetahuan, ketrampilan (keahlian) dan kemampuan ataupun karakteristik kepribadian yang mempengaruhi kinerja.

Pengertian kompetensi sebagai kecakapan atau kemampuan juga dikemukakan oleh Roe (2001:73) sebagai berikut : Competence is defined as the ability to adequately perform a task, duty or role. Competence integrates knowledge, skills, personal values and attitudes. Competence builds on knowledge and skills and is acquired through work experience and learning by doing “. Kompetensi dapat digambarkan sebagai kemampuan untuk melaksanakan satu tugas,nilai-nilai pribadi, dan kemampuan untuk membangun pengetahuan dan keterampilan yang didasarkan pada pengalaman dan pembelajaran yang dilakukan

Lebih lanjut bahwa kemampuan adalah suatu kapasitas individu untuk mengerjakan berbagai tugas dalam suatu pekerjaan (Robbins, 2001:46). Menurut Robbinsdan Judge, (2009:57) adalah kemampuan dipengaruhi oleh kecedasan intelektual 
(kecerdasan kognitif, sosial, emosional, kultural) dan kemampuan fisik artinya bila pegawai memiliki kecerdasan intelektual yang tinggi dan didukung kondisi fisik yang sesuai dengan kebutuhan pekerjaannya maka pegawai tersebut akan semakin mudah mengerjakan tugas-tugasnya sehingga akan mudah mencapai kinerja pegawai yang diharapkan. Dari definisi diatas jika kemampuan pegawai semakin meningkat maka pegawai akan semakin meningkat pula.

Secara lebih rinci, Spencer (Palan, 2007:84) mengemukakan bahwa kompetensi menunjukkan karakteristik yang mendasari perilaku yang menggambarkan motif, karakteristik pribadi (ciri khas), konsep diri, nilai-nilai, pengetahuan atau keahlian yang dibawa seseorang yang berkinerja unggul (superior performer) di tempat kerja. Dengan mencermati berbagai uraian tentang konsep kompetensi di atas, terlihat adanya hubungan erat antara kompetensi dengan kinerja. Hal yang sama juga dikemukakan oleh Prihadi (2004:38) bahwa :Kompetensi menghasilkan kinerja yang efektif dan/atau superior. Ini berarti kompetensi mempunyai hubungan yang erat dengan kinerja. Bisa dikatakan bila pegawai memiliki kompetensi di bidangnya maka pegawai tersebut akan meningkatkan kinerja yang efektif. Demikian pula bila motivasi kerja karyawan tinggi maka akan meningkatkan kinerja.

Pernyataan di atas mengandung makna bahwa kompetensi adalah karakteristik seseorang yang berkaitan dengan kinerja efektif dan atau unggul dalam situasi pekerjaan tertentu. Kompetensi dikatakan sebagai karakteristik dasar (underlying characteristic) karena karakteristik individu merupakan bagian yang mendalam dan melekat pada kepribadian seseorang yang dapat dipergunakan untuk memprediksi berbagai situasi pekerjaan tertentu. Kemudian dikatakan berkaitan antara perilaku dan kinerja karena kompetensi menyebabkan atau dapat memprediksi perilaku dan kinerja.

Upaya peningkatan kinerja yang dilakukan oleh tiap organisasi memiliki perspektif yang berbeda. Upaya tersebut berupa perbaikan kualitas sumber daya yang ada di dalamnya misalnya menetapkan kompetensi setiap staf, menyeimbangkan jumlah kerja dengan beban kerja, pemenuhan sarana fisik, perbaikan sistem manajemen dan memberi perhatian kepada seluruh staf serta menciptakan iklim kerja yang kondusif bagi organisasinya.

\section{3 Pengaruh Kecerdasan Emosional dan Kompetensi Terhadap Kinerja Pegawai}

Dari hasil penelitian membuktikan bahwa terdapat pengaruh antara kecerdasan emosional dan kompetensi terhadap kinerja pegawai. Artinya semakin maksimal kompetensi maka akan semakin baik pula kinerja pegawai. Sebaliknya, semakin rendah kecerdasan emosional dan kompetensi maka akan semakin rendah pula kinerja Penyuluh Badan Keluarga Berencana dan Pemberdayaan Perempuan (BKBPP) Kabupaten Garut.

Bahwa Sumber daya manusia merupakan hal yang paling utama dalam instansi, karena manusia selalu ada dalam suatu organisasi atau instansi. Sumber daya manusia merupakan tantangan tersendiri bagi manajer karena keberhasilan manajer tergantung pada kualitas sumber daya manusia. Apabila masing-masing individu dalam instansi dapat berjalan efektif dengan kata lain, kelangsungan instansi tergantung pada kinerja pegawai.

Kinerja pegawai yang rendah merupakan pencerminan dari organisasi yang memboroskan sumber daya yang dimilikinya, dimana pada akhirnya organisasi tersebut kehilangan daya saing yang akan mengurangi skala aktif itas usahanya. Kinerja pegawai yang rendah 
dari banyak organisasi akan menurunkan industri dan ekonomi bangsa secara menyeluruh yang cenderung mengurangi keberhasilan organisasi.

Hal tersebut sebagaimana pendapat Gibson (2003:14), ada tiga perangkat variabel yang mempengaruhi kinerja pegawai, yaitu: (1) Variabel individual, terdiri dariKemampuan dan ketrampilan: mental dan fisik, Latar belakang: keluarga, tingkat sosial, penggajian dan Demografis: umur, asalusul, jenis kelamin; (2) Variabel organisasional, terdiri dari: sumber daya, kepemimpinan, imbalan, struktur dan desain pekerjaan; (3) Variabel psikologis, terdiri dari: persepsi, sikap, kepribadian, belajar dan motivasi.

Lebih lanjut menurut Novitasari (2003:45) ada duavariabel yang dapat mempengaruhi kinerja pegawai, yaitu:(1) Variabel individual meliputi: sikap, karakteristik, sifat fisik, minat danmotivasi, pengalaman, umur, jenis kelamin, pendidikan, serta faktor individual lainnya.; (2) Variabel situasional, meliputiFaktor fisik dan pekerjaan, terdiri dari: metode kerja, kondisi dandesain perlengkapan kerja, penataan ruang dan lingkungan fisik (penyinaran,temperatur, dan ventilasi) dan Faktor sosial dan organisasi meliputi: peraturan-peraturan organisasi,sifat organisasi, jenis latihan dan pengawasan, sistem upah dan lingkungan sosial.

Adanya keyakinan yang dapat dipertimbangkan untuk menunjang konsep kinerja pegawai baru yang mengenai proses produksi sebagai suatu sistem yang kompleks dapat diterapkan dan berlaku dimasyarakat lingkungan, tenaga kerja, modal dan organisasi tidaklah penting dari dirinya namun dengan caranya terkoordinasi kedalam satu kesatuan yang terpadu. Keberhasilan kinerja pegawai organisasi diawali dengan sejauhmana kualitas kinerja pegawai para pegawainya.Untuk menegakkan kinerja pegawai organisasai menjadi lebih baik maka perlu menegakkan kinerja pegawai masing-masing pegawai.

\section{SIMPULAN}

Berdasarkan hasil penelitian pada masingmasing variabel dapat disimpulkan sebagai berikut :

1. Kecerdasan emosional berpengaruh positif dan signifikan terhadap kinerja pegawai. Artinya semakin baik kecerdasan emosional maka semakin meningkat pula kinerja pada Penyuluh Badan Keluarga Berencana dan Pemberdayaan Perempuan (BKBPP) Kabupaten Garut. Lebih lanjut berkenaan dengan kecerdasan emosional ditemukan indikator yang perlu lebih dioptimalkan berkenaan dengan keterampilan dalam berkomunikasi.

2. Kompetensi berpengaruh positif dan signifikan terhadap kinerja pegawai. Artinya semakin baik kompetensi maka semakin meningkat pula kinerja pada Penyuluh Badan Keluarga Berencana dan Pemberdayaan Perempuan (BKBPP) Kabupaten Garut. Lebih lanjut berkenaan dengan kompetensi ditemukan indikator yang perlu lebih dioptimalkan berkenaan dengan daya tanggap terhadap masalah.

3. Kecerdasan emosional dan kompetensi berpengaruh positif dan signifikan terhadap kinerja pegawai. Artinya semakin baik kecerdasan emosional dan kompetensi maka semakin meningkat pula kinerja pada Penyuluh Badan Keluarga Berencana dan Pemberdayaan Perempuan (BKBPP) Kabupaten Garut.

\section{DAFTAR PUSTAKA}

Hariwijaya, M., (2005). Tes Intelegensi Cara Akurat Mengukur Kecerdasan Intelektual Anda.

Ishizuka, T., Nakatani, K., \& Gibson, E. (2003). Relative clause extraction 
complexity in Japanese. In Poster presented at the 16th annual CUNY conference on human sentence processing, Massachusetts Institute of Technology, Cambridge, MA.

Mangkunegara, A. P., \& Prabu, A. (2005). Evaluasi kinerja sumber daya manusia. Bandung: Refika Aditama.

Novitasari, N. N., (2003). Pengaruh Stress Kerja Terhadap Motivasi kerja dan Kinerja Karyawan PT. HM Sampoerna Tbk. Surabaya.

Palan, R., (2007). Competency Management: Teknik Mengimplementasikan Manajemen SDM Berbasis Kompetensi untuk Meningkatkan Daya Saing Organisasi. Jakarta: PPM.

Prihadi, (2005). Assessment Centre, Identifikasi, Pengukuran dan Pengembangan Kompetensi. Gramedia Pustaka Utama. Jakarta.

Robbins, (2006). Perilaku Organisasi. Jakarta : PT. Indeks.

Roe, R. A., (2001). Pengertian Kompetensi. Tersedia: http://www. docstoc. com/[19 April 2009].

Suparno, E., (2005). Pengaruh Kompetensi, Motivasi Kerja, dan Kecerdasan Emosional Guru terhadap Kinerja Guru di SMP Negeri Se-Rayon Barat Kabupaten Sragen (Doctoral dissertation, Universitas Muhammadiyah Surakarta). 